Accepted refereed manuscript of: Hoffmann C (2018) Beyond the resource curse and pipeline conspiracies: Energy as a social relation in the Middle East, Energy Research and Social Science, 41, pp. 39-47. DOI:

10.1016/i.erss.2018.04.025

(C) 2018, Elsevier. Licensed under the Creative Commons AttributionNonCommercial-NoDerivatives 4.0 International

http://creativecommons.org/licenses/by-nc-nd/4.0/ 


\title{
Beyond the Resource Curse and Pipeline Conspiracies: Energy as a Social Relation in the Middle East
}

\author{
Clemens Hoffmann, University of Stirling
}

\begin{abstract}
This article identifies problematic tendencies in current analyses of the Middle East's energy relations. There is a tendency to see all social relations as determined by resource extraction, use and transfer, contributing to the uniquely instable social relations of the Middle East. The combination of weak governance and geological over-determination continues to damage the region's fragile ecology. Under these conditions, social structures are incapable to react to new crises, such as the effects of global climate change. This article offers an alternative, more optimistic perspective on the Middle East's energy relations. Privileging the social over the material, calorific, geological or topographic dimensions of energy relations, it argues that social life developed in relation to its natural resources, matter and energy, but is not singularly determined by it. It proposes to historicise and, thereby, repoliticise the Middle East's social energy relations, including its nutritional and geopolitical dimensions. This reveals their spatio-temporally dynamic, rather than materially determined character. Energy is subsequently re-defined into a political category, a field of social change rather than a limiting biophysical structure. The concept of Social Energy, thus, transforms nature from a constraining externality into an integral part of social analysis and transformation in the Middle East.
\end{abstract}

\section{Introduction}

The current global conjuncture is dominated by a multiplicity of crises. The financial crisis of $2007 / 8$ remains unresolved while Europe finds itself in the midst of a so-called 'refugee crisis', itself accompanied by a crisis of political sovereignty in the Middle East. This constellation appears to have turned into a political crisis in the West, too, with the rise of populist right-wing politics. Despite multiple sources of uncertainty, the hydro-carbon economy keeps growing, further aggravating the effects of anthropogenic global climate change. In sum, the world is at an intersection of crises, not infrequently formulated around the politics of oil or fossilised forms of energy. This concurs with the typically orientalised imagery of an instable political landscape in the Middle East where this 'abyss' is thought to be most evident. Providing simplistic, regionalised answers to complex global questions, such deterministic and orientalist narratives are not only problematic with regards to the Middle East itself. They obscure the inner workings of global crises, narrowing their origins geographically, offering mechanistic explanations, from population growth to cultural essentialisms and 'sectarian clashes' instead of meaningful social analysis.

This article reverses this logic by re-centring the Middle East's energy relations at the heart of an optimistic, rather than dystopian vision. It maps out a different, dialectical understanding of naturesociety relations. In doing so, it develops the 'Social Energy' approach, privileging the social over the material, calorific, geological or topographic dimensions of energy. Thus, energy is not treated as biophysical matter, but as historically and geographically specific set of social relations. This is not only meant to improve the analysis of energy politics. Social life, it argues, developed in relation to its natural resources, including matter and energy, but is not necessarily determined by it. It proposes to historicise and, thereby, re-politicise the Middle East's social energy relations. This reveals the spatio- 
temporally dynamic, rather than materially determined character of 'Social Energy'. Energy is, thus, understood here as a political category, a field of social change rather than a limiting biophysical structure. The concept of Social Energy, thus, transforms nature from an asocial, quantitative constraining externality into an integral part of social analysis and also, crucially, a potential source of social transformation in the Middle East. Finally, this paper will evidence this potential for emancipatory social change around Social Energy in historical practice detailing the case of the socalled 'Rojava' revolution in Northern Syria.

Energy politics in the Middle East is seen as more political than elsewhere. Energy and energy security are not only policy concerns, energy is frequently portrayed as integral to the many everyday conflicts in the region. For example, the never ending intra-Palestinian feud between Hamas and Fatah is carried out via Gaza's electricity supply from Israel. The Palestinian Authority (PA) stopped funding the already deprived coastal strip's supplies, leaving it not just without electricity, but also without substantial services such as waste water treatment and health services [21]. Saudi Arabia's geopolitical ambitions, enabled by the abundance of oil and the arms funded by its revenues, has not only become more interventionist in the region, but has also maintained low prices to undermine revenue and power of its rivals and competitors [72]. Both of these developments equally demonstrate political strengths as well as vulnerabilities related to energy, demonstrating that energy is ubiquitous in Middle East politics. No analysis of the region's complex relations is thought to be complete without considering at least an 'energy' component. Over time, however, the perception of this component has changed from being an enviable source of unlimited wealth to a poisonous curse, a social ill. While the need for hydrocarbon consumption has survived all political and economic crises in the West, the Middle East has gone through many ruptures in its relationship with energy.

Despite this centrality, surprisingly, notions of 'energy' or 'energy security' are mostly taken for granted and are hardly ever specified, let alone discussed [42]. Based on the region's geology, most 'energy' analyses of the Middle East, from security to geopolitics to political economy, remain focussed on hydrocarbons. Water-energy relations [62] and hydro-electric potentials are analysed within the context of transboundary river regimes, usually in relation to irrigation for agriculture. Apart from the financing of dam construction, water relations are rarely meaningfully related to the hydrocarbon economy. Similarly, analyses of renewable energy sources focus on the potential for solar and wind production for local use and potential electricity transfers to Europe, which still raises issues with vulnerability and security [45]. They are, however, hardly ever related to the complex geopolitical constellations within which they emerge [52].

What remains constant throughout time, space and different approaches to the Middle East's energy relations is an understanding of its environment as an exceptional case. This can come in the form of unprecedented riches, hardship, resource deprivation but is generally seen as 'unnatural nature'. The same humanity considered to be in control of its own destiny in subjugating nature in the north is disproportionately dominated by an environment not conducive to stability or development in the Middle East. This and the centrality of fossil resources to any analysis of the Middle East remain dominant in academic, journalistic and policy accounts [16]. Even if scarcity doesn't necessarily lead to outright conflict, the Middle East's political order is still seen as being dominated by its environment. Ever since Karl Witfogel's description of Oriental Empires having centralized politically due to their irrigation needs [74], an orientalist environmental determinism remains a popular form of analysing Middle East politics. Precarious environments and the assumed mismanagement by local elites served as a pretext for colonial rule in the name of paradoxically both rescuing as well as appropriating a 'pristine' nature [17]. Postcolonial states, via their ambition to project power in an insecure environment, are alleged to have reverted to the local mismanaged of both nature and government. More recently, climate change supposedly revealed the lack of 'resilience' or 'adaptive 
capacities' of these states. Arguments about Sudan's and Syria's civil wars being triggered by climate change [40],[61], collapsing the already fragile and dysfunctional post-colonial order into inevitable wars and devastation, close the cycle of modern 'Environmental Orientalism' in the ecological imaginaries of the Middle East.

This modern reading stands in sharp contrast to the emphasis of the Middle East's lush and productive environments, the origins of human agricultural cultivation in Mesopotamia and Palestine, making it the Biblical cradle of humanity itself. Even in the contemporary world, the Middle Eastern environment's perceived precarity can be contrasted with its central role in the global hydro-carbon economy and increasingly also the services industry. Different forms of appropriating nature are, thus, thought to sustain as much disrupt systems of rule, from the postcolonial all the way to the 'Islamic' state [20]. This is mirrored in the schizophrenic relationship to fossil fuel. This source of wealth [38], having degenerated into an outright "curse" [73], is now portrayed as inviting corruption, conflict and neo-colonialism. Once a catalyst of progress and development, the fossil curse is now thought to inhibit the kind of 'sustainable' social change beneficial for humans and nature alike.

This tension-ridden relationship between the 'precarious' environment and the political structures it generates, imposes or, indeed, destabilises, used to be expressed only in relation to water, climate and agriculture. Fossil energy, though a more recent discovery, is seen as just a disruptive social force in the Middle East's socio-political development. However, it's not just the hydro-carbon discoveries themselves that are meant to be problematic. Energy transfer routes, usually in the form of pipelines, invite conspiracy theories about the over-determination of the region's geopolitics. Syria's civil war quickly became a 'Pipelineistan War' [54],[47], where the US and Iran allegedly not only compete over Syria's resources, but also over major East-West energy transfer routes [23]. This emphasis on hydrocarbons as central to all Middle East geopolitics somewhat mirrors deterministic arguments about climate-change. A picture of the Middle East emerges that explains all conflicts, if not all social relations altogether with the absence or presence of its ecological features, from transboundary waters to geology to the topography relevant for energy transfers. It not only thought to explain the Middle East's own policies, but also those towards the region. Unsaturable 'Western' demand for oil supposedly imposes an imperial onslaught, generating all sorts of morbid phenomena, from the 'rentier' to the 'petro' [41], to the outright 'failed' state.

This article identifies these problematic tendencies in dealing with the Middle East's energy relations as a triple determinism. First, there is a tendency to understand all social relations as related to, if not determined by, the region's energy resources. Second, all resource extraction, use and transfer is thought to either cause or contribute to the uniquely instable social relations of the Middle East. Third, the combination of weak or morbid governance and geological over-determinism continues to damage the region's inherently fragile ecology. The socio-ecological damage, thus, supposedly becomes mutually reinforcing and irreversible. This Neo-Malthusian worldview, infused with an Orientalist understanding of the Middle East, offers little hope for escaping the resource, energy and social curses of the Middle East. While frequently criticised, the inherent resource and "energy reductionisms" [10, p 116] are rarely challenged directly. Resource curse, 'pipeline wars' and simplistic rentier state arguments remain popular also with otherwise critical analyses. In other words, while a deterministic and reductionist reading of the Middle East's energy relations is commonly accepted as a problem, little remedy is offered. The emphasis on quantitative positivistic energy studies, thus, continuously reproduces conventional analyses, making conflictual energy relations a self-fulfilling prophecy.

The following offers an alternative understanding of the Middle East's energy relations as social relations. It argues that, as elsewhere in the world, social life in the region developed historically "as an intricate web of relationships and flows of matter and energy" [38]. While this approach is by no 
means uniquely applicable to the Middle East, it is here that it proves not only most useful but also the most urgent for countering deterministic readings. The Middle East's energy relations, thus historicised and re-politicised, are seen as spatio-temporally specific. Nature is re-defined away from a biophysical, constraining element, into a social and political category, a field of socio-political struggle. 'Social Energy', therefore, moves from an asocial externality to an integral part of social analysis and, politically, to a source for potential social transformation.

This argument will be set out in three steps. First, the notion of energy as a social relation will be developed, denaturalizing the current carbon-based growth regime. Energy will be defined as a social relation that exceeds the relationship between hydro-carbons, electricity and social power. Going beyond purely chemical or economic properties of energy suggests an inclusion of nutrients, soils and human muscular labour as sources of energy. It also suggests a wider reading of the social and includes a historically sensitive notion of geopolitics. Second, this argument is contextualized in the Middle East, where conventional orientalist narratives of the region as a fragile and restrictive ecology and society are challenged. Using a single case study, it proceeds by identifying the unique but telling case of Social Energy in practice in the northern Syrian federal autonomy region ('Rojava', Kurdish for 'southern Kurdistan') and its 'Social Ecology' approach. Demonstrating the politically dynamic and potentially emancipatory, rather than restrictive nature of energy and its concrete social appropriation through a cooperative economy, the paper will close by arguing in favour of a 'Social Energy' approach, based on the careful historicisation of all social energy relations.

\section{Energy as a Social Relation}

Energy is usually understood in quantifiable terms, from kilo joules to kilowatt hours, millions of tons of oil equivalent or calories as a measure of nutritious value, to name but a few. Though energy can potentially take on a wide variety of social meanings, this quantifiable, kinetic understanding of energy remains dominant. Building on the biophysical quantification, its economic, monetized value, determined by international energy markets, informs most social science analyses as well as the practices and policies of securitizing energy [48]. Most social science literature, including that in International Relations (IR) has taken little note of the social dimensions of energy, and largely works with conventionally measured forms. Instead of infusing 'energy' with a social dimension, mechanistic laws of motion are also applied to the social world. The ultimate problem, then is that social energy relations are understood as an asocial mathematical reflection of bio-physical or chemical properties. Their economic value for social reproduction is accounted for by the 'raw' data only. More problematically, still, the inter-sections of nature and society, from hydro-scarcity to mineral abundance, are seen as extensions of a quasi-natural mechanism.

Instead of 'adding' energy to social analyses, what is suggested here is to understand energy research as a mode of social analysis itself. Without entirely rejecting those quantitative measurements, the social analysis suggested here moves beyond these economistic measures of nature. Most accounts on energy in the Middle East focus on minerals and/or fossil energy as highly flexible, mobile and high value resources around which the global political economic order was constructed. More recently, climate change research adds to this picture by accounting for the heat and emission dimensions of global energy flows. Different forms of energy relations, such as those emerging from the harvesting of gravitational energy through hydro-electric dams, complement this picture [51]. New sources of energy, and, specifically, new forms of electricity production, harvesting natural flows, such as wind and solar, are conventionally seen as challenging traditional power relations [29], but they may well serve to maintain them, too.

The production of space and nature [63] also implies the social production of energy, rather than only a passive harvesting of dormant potentials. This dialectical understanding of society and nature, thus, 
tries to overcome notions of energy purely as a commodity to be valorized in international markets and fought over by powerful states [14]. It aims to understand energy as an eminently social category, from the human body to large-scale infrastructure projects and global markets. This also implies that quantitatively measured energy resources are not merely physical, but also political. First, their emergence is closely related to the disciplining and subjugation of nature, both conceptually as well as materially. This is especially true in the case of the colonial subjugation of nature. Colonisation was quickly followed by post-colonial state building projects, many of which adopted and expanded the colonial economies. From British citrus cultivation and cotton plantations to the dam and irrigation construction projects of Non-Aligned states, most articulations of power, not least those opposing the West, involved forms of subjugating nature akin to the colonial regimes. More recently, nature's appropriation was led by its commodification in liberalised global markets and, more specifically, its financialisation [63].

Looking beyond its 'pure' calorific and economic value for providing heat, mobility and electricity as a physical dimension of the global circulation of capital, emphasizing the social dimension is evidently more difficult to capture in social analyses [31]. The logic of $21^{\text {st }}$ century financial capitalism characterised by an extensive use of algorithms [43], depends heavily on an automatized calculation of risk at the expense of qualitative human judgement. These structural changes, along with positivist social sciences informing policy making, privilege the kinetic over the social dimension of energy, not because they are more meaningful, but because physical quantities can be automatized more easily. There are of course physical, topographic and kinetic dimensions of energy within financial capitalism. While 'pristine' nature is increasingly financialized [78], most of the highly abstract risk, debt and derivative economies are more physical than is conventionally perceived. Not only does the production of hardware and processing capacity depend on energy resources. Financialisation also has implications for muscular energy, or labour, as the primary source for digital labour and the 'gig economy' [79]. The relationship between energy and social power is therefore not exhausted by the politics of minerals and hydro-carbons. Other forms of energy, especially food and labour, are geared into this increasingly automatized social energy metabolism. Given the intricate web of social relations within which energy occurs and by which it is transformed, the implied potential for social power is, however, much more difficult to understand.

Evidently, there is qualitative work trying to map these complexities, relating physical energy to social relations. The political economy, sociology and anthropology of energy deals with social energy relations. Some reflect on the role of producing technical knowledge in the making of energy policy [30], while others look at actual or potential conflicts around decarbonization, resource conflicts, or old and new 'energy imperialisms' [26]. The concept of 'energopower', for example, looks at the way in which the maintenance of Foucault's 'biopower' depends on the control of electricity and fuel [9].

Timothy Mitchell's work is particularly remarkable and applicable to the Middle East. It goes beyond a simplistic 'rentier state' model, problematizing the relationship between the actual production, processing and distribution of fossil resources and forms of social power [50]. Instead of maintaining a 'carbon autocracy' argument, his careful historicisation of socio-political energy relations demonstrates how the extraction and global re-insertion of mobile fossil energy and their maritime logistics helped disempowering labour movements which had controlled 'fixed' coal resources and railway transport. This relationship between different sources of energy and the reproduction of socio-political power, thus, produces spatio-temporally specific, rather than mechanistic social outcomes in energy producing and consuming countries alike [50]. While it also relates to local power relations, 'carbon statecraft' [8], is not immovable and bears global implications. Here, Mitchell points to the particularly important relation between energy and finance. For example, the reinvestment of oil revenues also includes intermediary effects far away from the original sites of oil production and consumption. Fossil energy, from coal to hydro-carbons, is indeed strongly related to the reproduction 
of social power in various complex ways. Similarly, research on hydropolitics demonstrates that the engineering of water resources is not just designed to harvest gravitational energy, control floods and abstract irrigation water [66]. Water infrastructure is frequently used to 'hydro-demographically' engineer societies, displace minorities [33] or project power geo-politically [36]. These different forms of energy also relate to one another: Hydrocarbon revenues and the associated finance industry are central for funding large hydro-electric schemes. Irrigation infrastructure, in turn, is central for industrialised agriculture and, hence, food security, which is always a strategic concern for states in the Middle East. Oil revenues fuel further, frequently unsustainable investment in land and agriculture, mostly in Africa [75],[13]. These investments in irrigation schemes are, in turn, related to other practices of social engineering, land grabs and the violent introduction of new labour regimes [44].

These various complex relations suggest a re-thinking of the relationship between energy and power beyond the fossil fuel and electricity infrastructure. Other related social energetic relations not captured by the conventional literature include, most importantly, the energetic implications of agricultural development, food production and the nutrition they produce. These, in turn, relate to property and labour, or muscular regimes, usually organised by political communities. These communities, in turn, relate to one another, sometimes in geopolitically competitive or cooperative ways. All of these are integral parts of the social infrastructure through which energetic matter circulates.

Nutrients of the soil, lost through unsustainable forms of agriculture, are also nutrients for human energy. Biophysically, the energetic value of food is not exhausted in measurable calories, but food is also a source of human metabolic energy and, by extension, public health. While not directly a source of energy in and of itself, public health and the institutions maintaining it are central to maintaining the circulation of energy through human and animal bodies within highly toxic modern societies. This, in turn, relates to a central category in all social analysis: human labour. Spatio-temporally specific labour regimes relate to specific forms of irrigation and other forms of environmental management. These are embedded within global value chains and determined by local, national and international agricultural, food security, development and health policies. Understanding metabolic social energy relations [60], thus, directly includes nutrition and indirectly healthcare provisions to account for all social energy relations beyond the more rehearsed hydro-carbon/electricity link.

Looking at those metabolic social energy relations reveals the increasingly "unhealthy circulation of matter", as Marx described it [11, p12], within human bodies, eco-systems, and, by extension, societies. Energy, labour, social property relations and soil fertility are in fact closely related in their increased overexploitation. Engels described how the closure of common land in Germany had led peasants to intensify energy use (initially in the form of cattle, later including fertilizers and industrial mechanisation) to maintain income and yields while cultivating less land [25, p116]. This intensification of both human exertion in the form of wage labour and non-human extraction of energy in the form of soil nutrients leads to increased environmental degradation and infertile land. Human physiology, the base of labour power, is similarly strained and can be physically harmed by the excessive release of heat, toxins and unhealthy circulation of matter more generally. The combination of environmental and human harm consequently also tires societal structures in general, straining health and other public services. More than just an over-extraction of soil nutrients, industrialised global food regimes are integral to this process. With an increased investment in land by foreign investors, they also constitute another form of south-north energy transfers. Over-extracted nutrients, entered into high protein diets, are usually consumed by wealthier populations in the global north. This unequal relationship of exchange is not dissimilar to the trade in hydro-carbons. 
This is not to suggest that social energy relations are bio-physically determined. Rather, social energy relations need to be contextualised within historically specific forms of power. This includes technologies of energy extraction, production, consumption, transmission and storage, generated by specific social formations. For example, the invention of the internal combustion engine by a German engineer didn't revolutionise the world economy. It was only its mass production within the US capitalist social formation that this innovation became the core of a new industrial age and, eventually a new global order. Institutionalised labour regimes, urban planning centred around mortgage fuelled real estate expansion, which in turn required individual mobility, usually based on hydro-carbons are all elements in this order. This model of growth was globally transmitted in the post-war years through international financial institutions. To this day, industrial policies around the world tend to see the automotive, energy, real estate and finance industries as pivotal to processes of 'development' and growth. Politically, however, these policies tend to consolidate north-south power inequalities implied in the international division of labour. Despite the growth in renewables, there's no sign of abating this trend. Global data flows are still based on vast electricity, mineral and cooling resources. Fossil fuelled global air travel and high-volume shipping, including that in minerals themselves, remain major pillars of this order.

Economic and fiscal policies are also geared into this post-45 global energy regime. The planning of public, hydro-carbon based infrastructure, financed with the help of international donors, institutions and markets, maintains growth as much as it maintains hegemonic power relations. It also sustains the continued carbon based urban planning, including mass transport. These relate to the increased casualisation of 'flexible' labour. Priced out of the booming, if speculative real estate markets closer to the commercial centres, even average income earners are forced into urban peripheries, generating increased demand for transport. This post-war regime also carries additional public health implications. Human energy sustaining this labour power is harmed by having become more sedentary and yet more mobile at the same time. Fed by the supply of high energy industrialised diets causes problems from obesity to malnutrition to cardiac disease [57]. At the intersection of the global social and the human metabolisms, these energy transfers maintain old and create new global inequalities, exploiting soils, nutrients and labour in the south before channelling their energy content to wealthier parts of the world where they create unhealthy abundances. At the same time, they maintain hegemonic forms of rule.

Even if looked at more holistically, energy transfers are not just carried out by global markets. Transnational capital relations co-exist within a system of nation-states, many of which have related, if not always outright competitive energy and development policies. Much of traditional geopolitics, broadly defined as the question of how geo-physical space is politicised, remains within the neoMalthusian/realist paradigm of a generic, a priori assumed and under-specified competition over territory and scarce resources. Geopolitics in the current context of social energy relations is understood here more widely as the relationship between society and nature, mediated by the interaction between different societies, or 'the international'. Critical political economy, inspired by world systems theory has reflected on the international and its energy implications, focussing on unequal relations of exchange, primarily in the form of resource trade [26]. Though drawing out this relation is important, it nevertheless neglects the historical conditions under which the global South emerged and continues to develop. These conditions include, most importantly, that of colonialism and subsequent competitive post-colonial state developmentalism. Not only is the world's indivisible biosphere in fact divided into multiple jurisdictions. They have also entered a process of competitive development, not reducible to conflict. The relationship between geopolitics and energy, therefore, goes beyond the classic distinctions between realist pessimistic expectations conflict, liberal optimistic expectations of trade and cooperation or Marxist expectations of neo-colonial domination and resource extraction. Rather than assuming universal outcomes a priori, the concrete forms these relations take, remains historically specific. Inter-societal relations always do relate directly to the way 
in which nature is appropriated. This frequently takes on a competitive, sometimes a cooperative and not always a conflictual nature. Understood in those terms, geopolitics carries major biophysical as well as social, but by no means pre-determined energetic implications.

Before proceeding to the next section of how this social understanding of energy applies to the contemporary Middle East and how such an analysis can improve our understanding of the region more generally, the following will summarize the core assumptions developed above. First, it was argued that energy, rather than being 'accurately' represented by quantitative calorific or electric measures, is in fact better understood as a social, historically specific category. Energy understood as a social relation is, thus, not universal, transhistorical or easily, if at all, quantifiable. Rather, it is socially and spatio-temporally specific. Social Energy is, thus, part of a notion of the social metabolism which approaches nature-society relations as a whole. Economically as well as ecologically societies' exchange relations are not just with other societies, but with all material and energetic matter. The lens of social metabolism, thus, doesn't merely look at the usage of energy, or input alone, but looks at the entirety of the energetic cycle, or physical throughput of a socio-economic system, including humanity as part of all living matter [80]. The social metabolism is, therefore, not reducible to mechanistic laws of nature.

This applies to the Middle East in peculiar ways. Here hydro-carbons simultaneously represent easy access to wealth and power as well as a potentially degenerative social and ecological poison. Second, it was emphasized that the conventional focus on minerals and hydro-power overlooks a crucial element in the global social energy metabolism, namely nutrition and, by extension, health. This not only includes agriculture, soil and climate, but also food itself as a source of energy, i.e. the conditions for human social reproduction in the form of labour and the public institutions that maintain it. Third, it was argued that 'energy', thus socially defined, is mediated not only by a global, universalising and homogenising capitalist world market, led by the financial industry, but also by geopolitics understood as the historically specific ways in which societies interact in their appropriation of nature. Without reducing these geopolitical energy relations to a simplistic 'scramble for resources' narrative, the Middle East is indeed conditioned by competitive post-colonial state building projects. The following will situate these arguments empirically within the context of the Middle East and northern Syria more specifically.

\section{Social Energy Relations in the Middle East}

In many ways, the Middle East is a region where the complex relationship between conventional understandings of energy, agriculture, food and geopolitics plays out in the most obvious fashion. The region's endemic problems with socio-political and ecological instability in an energy rich environment can be read into the multiple contemporary crises and conflicts. Especially conventional hydro-carbon energy relations from Libya to Syria continue to serve as explanations for the origin and escalation of conflicts [36],[1]. Control over resources is thought to motivate conflicting parties, be that "revolutionary states," [15] old and new imperial powers [76]. In sum, Middle Eastern society is thought to be dominated by the political economy of mineral extraction and the imperial powers competing over those resources.

Though not all states match this description, the 'rentier' state model has become a popular way to analyse the proto Middle Eastern state under these conditions. Typically, these states extract rents from hydrocarbon extraction. An oligopolistic energy market and a geopolitical umbrella provided for by a 'hegemonic' West maintaining carbon capitalism [18] sustains oil-producing authoritarian elites [5]. Crucially, the political maintenance of these regimes doesn't require taxation which would necessitate political compromises. In combination with the arms industry's abundant supplies in exchange for petro-dollars, this allows for a greater degree of autocracy and cronyism than would be 
possible elsewhere [59]. Harvesting these rents also works as a disincentive to develop a meaningful industry and a politically powerful labour force that comes with it. This sets in motion a path of highly uneven development, harvesting cheap casual labour from the third world, expanding oil-revenue funded services, logistics and real estate sectors. Though this 'model' is developed mostly with a view to the relatively homogenous block of the Arab oil producing member states of the Gulf Cooperation Council (GCC), it is frequently applied to other producing states and came to represent the region's political nature as a whole.

Elements of this concept are applied to societies and regimes as diverse as Iran's theocracy to an effectively 'failed' (or 'failing') state of the Syrian Arab Republic. All (geo)politics is related to or determined by its relation to hydro-carbon resources. Iran's engagement in the Syrian Civil War is at least as much motivated by its desire to secure a hydro-carbon export route through its Mediterranean coastline as by its support for the Lebanese Hezbollah [34]. In the wider region, geopolitically powerful and influential states like Egypt and Turkey, while not meaningful producers in themselves, are still seen to be determined by the regional geopolitics of energy [68], aspiring for a role as 'energy transfer hub' [19],[69]. 'Normalization' deals between Turkey and its former adversary Israel have caused many analysts to identify the energy link as the ultimate cause for what amounts to a dramatic foreign policy shifts [28].

These examples illustrate a common over-emphasis of energy when analysing the Middle East's social fabric and its geopolitical relations. Understanding the Middle East as a dysfunctional export oriented primary commodity producer subject to imperial interests not only neglects its role as a source of demand, consumption, distribution and transformation of energy. It also tends to under-specify the nature of individual societies, their historical conditions of emergence and the central, but socially complex role of energy in these state-building projects. As elsewhere, the post-war growth regime didn't create a homogenous world after capitalism's own image. Neither did it produce homogenous societies amongst producer countries in the region, following a 'logic' of hydrocarbon capital accumulation.

As Adam Hanieh convincingly argued, not even the seemingly homogenous block of the GCC countries can be subsumed under the same logic [32]. One of its member states, Qatar, is currently under a regime of sanctions by its fellow rentiers, necessitating food supplies via air links. This example vividly demonstrates the dynamic relation between all different forms of energy, the reproduction of social power and geopolitics in the Middle East. It also shows that a static rentier state theory cannot capture the complexities of the contemporary Middle East. Despite its mineral wealth, Qatar's and the Middle East's energy relations are far from fixed or stable. Rather than combining energy determinism with similarly problematic identity politics, sociology of religion or culture, what is suggested here is a greater specification of the historical origins of energy relations and how they enter the social and geopolitical fabric of the Middle East. More specifically, many of the origins of both energy production and consumption can be found in the various national developmentalist projects. These, in turn, are rooted in colonial legacies and the historical development of competitive post-colonial regimes, the legacies of the cold war and new forms of imperialism [2].

\section{Syria's Old and New Energy Relations}

Hence, the current critique is not so much meant as a denial of the importance of energy or oil for understanding the Middle East and its conflicts. It does, however, try to overcome a simplistic understanding of 'energy as hydro-carbons' and an over-determination of society by them. 'Social energy' means that, apart from oil, it is land, soil, food, nutrition and the associated social property relations that need to be analysed to allow for a more holistic understanding of energy relations in the Middle East. Hydro-carbons, while still relevant, have served to obscure other, similarly or sometimes even more important energy relations. For example, the role or politics of bread supply and subsidies 
in the Middle East has long been emphasised as one of key strategic importance [46]. In the case of the Syrian civil war, conflicts over wheat [22], its pricing [24], the supply of seeds or the flour delivered by international humanitarian aid agencies [4] are as important as the access to electricity, diesel to fuel military operations or maintaining or gaining control over any strategic territory.

In order to fully understand these complex social energy relations by way of example, the following will develop a deeper understanding of some of the energy relations of the Syrian civil war. It will first elaborate on the political developments that gave rise to the current situation before looking at alternative forms of energy relations in the northern Syrian autonomy regions. This will demonstrate the socially complex, politically dynamic forms of energy present in the region. It will close by emphasizing that these alternatives, while valuable, operate within geopolitical contexts, which can both catalyse or disable their political ambitions.

\section{The Origins of Syrian Development}

The Syrian Arab Republic emerged from the French colonial mandate, following the collapse of the Ottoman Empire during the First World War. The colonial mandate system left most social structures, characterised by systems of patronage, linking direct producers with the imperial center, in place. Liberal reforms brought only few changes to the social structures, but allowed for private property and, hence, the limited development of a landed class [35, p244]. This was radically reversed once Syria gained full independence in 1946. Development was strongly characterised by the anti-colonial, geopolitical vision of Syrian Arab independence of the Ba'athist regime. Nationalising all land by removing the colonial landed nobility was part of a semi-socialist experiment empowering the state bureaucracy and the military [35, p246]. In line with a defensive thinking on national autonomy, this regime included visions of agricultural self-sufficiency, which, however started showing cracks and contradictions in the 1970s. This led to a liberalisation of the land regime, or infitah, bringing back some of the old landed elites, while still relying heavily on oil income to subsidise food production [55].

These policies also implied an ethno-demographic element, marginalising minorities, such as the Kurds. Traditionally settled in the north of the country, they became the target of 'Arabization', or Arab Belt policies, turning the Kurdish majority areas in the north of the country into primary commodity production. Having traditionally been viewed as the 'breadbasket' of Syria, this marginalisation involved limitations on political rights, sometimes including citizenship itself. Infrastructure investments, including those in energy, were in line with this policy. Low-yielding wheat and beans used dry farming and landless Kurdish labour. The fertile high yielding and water intensive production in the Euphrates valley was left in the control of loyal Arab tribes. All processing remained located in areas closer to the centres of power in Damascus and Aleppo. Similarly, oil drilling was separated from refining, channelling surplus value and economic wealth of fossil resources away from the locales of production. In other words, the Ba'athist state saw the Kurdish areas mostly from an internal colonial perspective politically maintaining uneven development.

When the Syrian civil war broke out in 2011, partly in reaction to the job losses, rural poverty and environmental degradation resulting from renewed neoliberal policies, the Assad regime withdrew from the northern areas to concentrate its forces against the greater threat of the 'Free Syrian Army' (FSA). After the withdrawal was complete in 2014, the Kurdish political movement not only organised militarily, building up Kurdish People's Protection Units (Yekîneyên Parastina Gel, YPG) and the associated Women's Protection Units (Yekîneyên Parastina Jin YPJ), but also initiated a 'libertarian' confederalist municipalist project borrowed from the American anarchist thinker Murray Bookchin. At its core, the project intends to build up decentralised communal political structures in local 
assemblies and specialised committees, circumventing, if not directly challenging the traditional structures of the nation-state [12]. This also includes principles of social ecology and feminism as the two associated pillars. Social ecology aims at a more sustainable form of communal and cooperative agricultural production, dissolving the hierarchy between man and nature. To Bookchin, ecological exploitation and the cartesian ontology that enables it are one of many expressions of old, socially corrosive hierarchical class and gender relations that are maintained by the state to favour capitalism. Thus, dissolving relationships of domination, both of 'man over man', 'men over women' and 'humanity over nature' is part of a strategy of social change, rethinking society along an open-ended dialectic [7]. This includes a dialectical naturalism, rather than ecological monism, which allows for the formulation of future restorative relations with nature, including technological innovation. While introduced by Murray Bookchin, the use of 'Social Ecology' here exceeds the original main purpose of developing this concept as a political building block of his "democratic confederalist", decentralised, cooperative economy. This term may well be used more widely and more analytically, implying that all social relations are at the same time ecological (as well as energetic) relations [81]. The term is more specific and more programmatic in its focus on nature-society relations than 'social relations', however, it is not meant to replace the latter here.

In practice, an integral part of this project now formally organised as the "Democratic Federal System in Northern Syria", was to reverse years of political marginalisation and deliberate underdevelopment. These plans were, however, conditioned by the geopolitical situation, both positively as well as negatively. First, the YPG's existential struggle against the so-called 'Islamic State' (IS), or Daesh, eventually created a geopolitical space, protected by great powers, for the project to thrive and expand territorially. This includes control over valuable land, water and oil resources. Despite the public focus on the IS oil trade for the fiscal maintenance of its rule, controlling large parts of the fertile, high yielding river valleys along the Euphrates and its tributaries was more important for its fiscal income than oil revenues [71]. Syria's major water and energy infrastructure, including three strategically important hydro-electric dams constructed by the Ba'athist developmental vision, are also located in the valley [77]. Left with the legacy of internal colonialism, Kurdish held areas, by contrast, had relied mostly on pump irrigation using poorly refined fuel. This made the opportunity to capture dams and their electric potential an attractive side effect in their struggle against IS.

\section{Energy and Social Ecology}

Apart from the agricultural transformation towards sustainable cultivation, crops rotation, cooperatives and self-sufficiency, social ecology entails the 'democratization' of energy as well as low carbon growth. This ambition to escape the fate of the 'rentier state' faces major challenges. One, it raises the question of how to incorporate the by now significant oil resources under the federation's control, avoiding a resource curse. Given the project is not per se anti-developmentalist, its current energy needs, including those for agriculture and irrigation, are mostly met by fossil fuel based generators, which tend to break down due to the poor quality of the oil [70]. Two, the oil wealth in northern Syria is central to maintaining the war effort, including revenues from sales to third parties, mainly the Syrian government. Third, according to the traditional logic of pipelines and the valorisation of oil in international energy markets, there is some speculation whether the project would be funded by the potential proceeds from independent exports via the Eastern Mediterranean. Such a strategy would privilege a geo-territorial logic over the political substance of the project. However, a de-facto embargo and the lack of expertise in oil technology make these options less likely. The lack of refinery capacity or market access means that the oil wealth is to be retained domestically which may benefit future reconstruction efforts. Consciousness about the project of social ecology also means that there are attempts to evade this dependence on oil altogether, which leads to the planning of wind and 
small hydro-power projects. Especially in the Afrin region, which is a de-facto enclave surrounded by hostile forces, this is also of strategic importance [59]. Hence, the political economy of energy in Rojava appears, for now, to escape the conventional energy logic of the Middle East. This is partly due to the revolutionary nature of the political project, taking decisions in committees and organising energy and agriculture in collectives, partly because of the limited geopolitical space the general military situation offers.

\section{Agricultural Alternatives}

Agricultural development, similarly, is an integral part of the project. Its main aim is to reverse the ills of the past, characterised by monocultures, heavy use of chemical fertilisers and soil exhaustion. Diversification is a key element, not just as a step towards food sovereignty and nutritional balance, but also to become more sustainable. Crops conversion proves difficult, though, as these areas also suffer from an embargo preventing the import of many items from seeds to fertilizers. In reaction to the embargo and soil exhaustion, the so-called 'Rojava Plan' proposes to expand local subsistence production using organic fertilizers, collected from local household waste [67].

The production of organic fertilizers is the first project implementing organic self-sufficient production operationalizing Bookchin's principle of social ecology and democratic confederalism, which also entails education as one of its other major pillars. The plan has identified a need for fertilisation in the broader social transformation, politicising soil health and human nutrition by integrating it into the system. The new system collects household organic waste, processes and redistributes it to agricultural cooperatives [56]. However, the introduction of the fertilizer project not only implements organic agriculture and helps overcoming shortages generated by a history of deliberate underdevelopment and the current embargo. It also provides the ground for the diversification of agriculture in the future [53]. It also cultivates educational tools as a key pillar in the social transformation intrinsic to the political project. While these experiments are still small-scale, they still represent a major step in the direction towards social change. However, these social innovations can only thrive given the abundant availability of land resources in northern Syria. For historical reasons, most of the land used to be state land, which has become available owed to the regime's withdrawal. Questions of how to transform the social property regime underlying these changes are therefore less pressing as the communal self-administration doesn't have to risk social unrest. How this would play out in contexts where private property is widely spread or a functioning state authority controls resources, land and labour more tightly.

As the experience of northern Syria shows, it is not just the process of decision making itself and the everyday politics of maintaining rule in the provision of 'soft' public services such as education that are openly political and social in nature. Similarly, the 'hard' or physical infrastructures, from electricity production to agricultural infrastructure do not just provide public goods, such as food, water, shelter, health and energy, but are organically linked to the social project, making it 'lively' infrastructure [3]. Just like the maintenance of certain rural and urban property regimes imply the installation of corresponding physical structures, so does any project of socio-political change demand adaptation of practices of 'infrastructuring' [6], or geo-spatial re-modelling. This includes nature and energy resources beyond the extraction and valorisation of fossil fuels. And though this intention of moving towards a social ecology may become part of a successful challenge to dominant power (infra)structures, it also bears the risk of producing new contradictions.

Here, again, the history of state-formation in the Middle East which gave a 'tormented birth' to the Syrian Arab Republic, cannot be overlooked. The formation of developmentalist post-colonial states in the Middle East and the way they appropriated nature in an internationally competitive process may still apply to the current project. The Euphrates valley has been the source of a transboundary 
row between Ankara and Damascus in the past. Syria's hosting of PKK bases in the 1990s was related to Turkey's upstream construction of the Ataturk Dam and a transboundary water crisis that nearly ended in armed confrontation. Within Turkey itself, the irrigation systems surrounding the larger dam system, called the 'Southeast Anatolian Project' were designed to socially control a marginalized Kurdish workforce in newly established irrigated farms. When the YPG gained control over the hydroelectric facilities on the Euphrates, the Tishreen and the Tabqa dams, this offered opportunities, sustaining the reconstruction effort and maintaining self-sufficiency in electricity supply. However, it also generated a major source of geopolitical vulnerability. Having declared the Democratic Federal System in Northern Syria an existential threat, Turkey now withholds water upstream, only to release it in intermittently, causing shortages in electricity and water supply as well as floods [65]. Internal contradictions like the question of how, if at all, to market fossil resources and external problems, such as the transboundary issues along the Euphrates constitute challenges to the praxis of social ecology.

However, it is precisely here in the realm of practicing a social ecology under the conditions of warfare and isolation that a more inclusive notion of energy comes to fruition. Looking exclusively at hydrocarbons in a complex civil war environment doesn't offer a meaningful insight. It neglects different forms of energy like agriculture and the social regimes that sustain them, including property and labour relations, but also geopolitics. Just as hydrocarbons themselves, newly opened geopolitical spaces don't just constrain social development, but also enable alternative energy relations as vehicles for socio-political alternatives.

\section{Conclusion}

The preceding story of alternative social energy relations in northern Syria serves to demonstrate that conventional assumptions about a structural determination of rentier states by the political economy of hydrocarbons embedded within competitive geopolitical relations is not a natural social order in the Middle East. A long history of colonialism, state-formation and dynamic geopolitical relations from the cold war to the Arab-Israeli conflict, have shaped the contemporary regional order and the political forms taking shape within it. Typically, this involved post-colonial, developmentalist and militarized regimes, socially engineering society and nature top-down for defensively in a competitive regional order. Social energy relations, from the local to the global, are an integral part of these socio-historical dynamics more than determining them top-down.

This confirms the basic assumptions set out from the start, namely that nature is political, however, not in static, deterministic or universal ways. Local ecologies and conflicts are not natural outcomes of the political economy of energy, but are mediated by historically specific imperial and post-colonial developmental regimes and their position within regional and global orders. Rather than determining social life, the way in which energy is socialized and politicised into these complex environments is spatio-temporally specific. 'Social Energy' is more than just the mathematical or quantifiable equivalent of kinetic energy, heat and entropy. It is better understood as a field of social struggle with an inherent potential for social empowerment and, hence, change. Applied to the Middle East, this means that the sociology of energy has the potential to overcome deeply orientalist analyses portraying the region as determined by its physical-geological properties, inevitably leading to social corrosion and instability. While energy, and specifically fossil fuel extraction and marketization are indeed central to understanding the region's geopolitical dynamics, the current argument emphasized the complex, historically grown and geopolitically dynamic relations of the region. This includes, first and foremost to identify the human social motivations behind the region's energy relations, their historical constitution are all parts of this story. Second, it was argued that agriculture, soil, nutrition, 
human labour and the social property regimes within which they exist, are central to understanding this broader notion of social energy. Third, a socially dynamic non-deterministic notion of geopolitics was introduced to complement this picture. Energy is subsequently re-defined into a political category, a field of social change rather than a limiting biophysical structure. The concept of Social Energy, thus, overcomes the notion of nature as an asocial, constraining externality into an integral part of social analysis and a potential source of social transformation in the Middle East.

[1] Ahmed, Nafeez. "Peak oil, climate change and pipeline geopolitics driving Syria conflict." The Guardian, May 13 (2013).

[2] Al-Khafaji, Isam. Tormented births: passages to modernity in Europe and the Middle East. Vol. 39. IB Tauris, 2004.

[3] Amin, Ash. "Lively infrastructure." Theory, Culture \& Society 31.7-8 (2014): 137-161.

[4] Beals, Emma. "Assad Expels Aid Groups as Syria Starves", The Daily Beast, 29/05/2014, available at: http://www.thedailybeast.com/assad-expels-aid-groups-as-syria-starves (accessed June 10, 2017)

[5] Beblawi, Hazem, and Giacomo Luciani, eds. The rentier state. Routledge, 2015.

[6] Blok, Anders, Moe Nakazora, and Brit Ross Winthereik. "Infrastructuring environments." (2016): 1-22.

[7] Bookchin, Murray. The ecology of freedom: The emergence and dissolution of hierarchy. Palo Alto, CA: Cheshire Books, 1982.

[8] Boyer, Dominic. "Energopolitics and the Anthropology of Energy." Anthropology News 52.5 (2011): 5-7.

[9] Boyer, Dominic. "Energopower: an introduction." Anthropological Quarterly 87.2 (2014): 309333.

[10] Burkett, Paul, and John Bellamy Foster. "Metabolism, energy, and entropy in Marx's critique of political economy: Beyond the Podolinsky myth." Theory and Society 35.1 (2006): 109-156, 116

[11] Burkett, Paul. Marx and nature: A red and green perspective. Springer, 1999. P 12

[12] Cemgil, Can. "The republican ideal of freedom as non-domination and the Rojava experiment: 'States as they are' or a new socio-political imagination?" Philosophy \& Social Criticism 42.4-5 (2016): 419-428.

[13] Cochrane, Logan, and Hussein A. Amery. "Gulf Cooperation Council Countries and the Global Land Grab." The Arab World Geographer / Le Géographe du monde arabe Vol 20, no 1 (2017) 1741; Pfeiffer, Dale. Eating fossil fuels: oil, food and the coming crisis in agriculture. New Society Publishers, 2009.

[14] Colás, Alejandro, and Gonzalo Pozo. "The value of territory: Towards a Marxist geopolitics." Geopolitics 16.1 (2011): 211-220.

[15] Colgan, Jeff D. "Oil and revolutionary governments: Fuel for international conflict." International Organization 64.4 (2010): 661-694.

[16] Davis, D. K., \& Burke, E. (2011). Environmental Imaginaries of the Middle East and North Africa. Ohio University Press.

[17] Davis, Diana K. "Imperialism, orientalism, and the environment in the Middle

East." Environmental imaginaries of the Middle East and North Africa (2011): 1-22, p 3.

[18] Di Muzio, Tim. Carbon Capitalism. Energy, Social Reproduction and World Order. Rowman \& Littlefield International, 2015.

[19] Dieke, Linda, and Mirja Schröder. "Turkey as an Energy Hub? Introduction to Turkey's Role in EU Energy Supply." Turkey as an Energy Hub?. Nomos Verlagsgesellschaft mbH \& Co. KG, 2017.

[20] Eklund, Lina, et al. "How conflict affects land use: agricultural activity in areas seized by the Islamic State." Environmental Research Letters 12.5 (2017): 054004. 
[21] Eldar, S. Gaza's Ticking Sewage Bomb, Al-Monitor, June 16, 2017, available at: http://www.almonitor.com/pulse/originals/2017/06/israel-gaza-strip-palestinians-elecrticity-ecology-

water.html (accessed July 6, 2017)

[22] Enab Baladi English "Three Parties Are Fighting Over the Wheat of Al-Hasakah Governorate", Enab Baladi English, 29/05/2017, available at:

http://english.enabbaladi.net/archives/2017/05/three-parties-fighting-wheat-al-hasakahgovernorate-al-jazira-province/ (accessed July 2, 2017)

[23] Enab Baladi English 'Gold is under the Dunes. Many Countries Craving for the Syrian Badia', Enab Baladi English, July 18, 2017, http://english.enabbaladi.net/archives/2017/07/gold-dunesmany-countries-craving-syrian-badia/ (accessed June 22, 2017)

[24] Enab Baladi English "Wheat War in Northern Syria Reveals Fragmentation of Rebel Groups", Enab Baladi English, 06/06/2017, available at:

http://english.enabbaladi.net/archives/2017/06/wheat-war-northern-syria-reveals-

fragmentation-rebel-groups/ (accessed July 2, 2017)

[25] Engels, Frederick, "The Mark," in Karl Marx and Frederick Engels, Collected Works, Vol. 24

(New York: International Publishers, 1978): 439-456., quoted in Burkett and Foster (2006)

[26] Foster, J. B., \& Holleman, H. (2014). The theory of unequal ecological exchange: a Marx-Odum dialectic. Journal of Peasant Studies, 41(2), 199-233

[27] Foster, John Bellamy. "Peak oil and energy imperialism." Monthly Review 60.3 (2008): 12.

[28] Girit, Selin. 'Gas pipeline hope heals rupture in Israel-Turkey ties', BBC News, 19 October

2017, available at: http://www.bbc.com/news/world-europe-37692753 (accessed June 20, 2017)

[29] Goodman, James, and Ariel Salleh. "The 'green economy': class hegemony and counterhegemony." Globalizations 10.3 (2013): 411-424.

[30] Guy, Simon, and Elizabeth Shove. The sociology of energy, buildings and the environment: Constructing knowledge, designing practice. Routledge, 2000.

[31] Haberl, Helmut, et al. "Quantifying and mapping the human appropriation of net primary production in earth's terrestrial ecosystems." Proceedings of the National Academy of

Sciences 104.31 (2007): 12942-12947.

[32] Hanieh, Adam. Capitalism and class in the Gulf Arab states. Springer, 2016.

[33] Hashim, Muhammad Jalal. "The dams of Northern Sudan and the policy of demographic engineering." International Journal of African Renaissance Studies 5.1 (2010): 148-160.

[34] Hiltermann, Joost: "Syria: The Hidden Power of Iran", The New York Review of Books, April 13, 2017, available at http://www.nybooks.com/daily/2017/04/13/syria-hidden-power-of-iran/ (accessed June 20, 2017)

[35] Hinnebusch, Raymond A. "State and civil society in Syria." Middle East Journal 47.2 (1993): 243-257, 244

[36] Hoff, Brad: "Hillary Emails Reveal True Motive for Libya Intervention" Foreign Policy Journal Jan 6, 2016, available at: https://www.foreignpolicyjournal.com/2016/01/06/new-hillary-emailsreveal-true-motive-for-libya-intervention/ (accessed July 20, 2017).

[37] Hoffmann, Clemens. "From Small Streams to Pipe Dreams-The Hydro-Engineering of the Cyprus Conflict." Mediterranean Politics (2017): 1-21.

[38] Huber, Matt. "Energy and Social Power - From political ecology to the ecology of politics". Perreault, Tom, Gavin Bridge, and James McCarthy, eds. The Routledge handbook of political ecology. Routledge, 2015., pp 481-492

[39] Huber, Matthew T. "Oil, life, and the fetishism of geopolitics." Capitalism Nature Socialism 22.3 (2011): 32-48.

[40] Kelley, Colin P., et al. "Climate change in the Fertile Crescent and implications of the recent Syrian drought." Proceedings of the National Academy of Sciences 112.11 (2015): 3241-3246 [41] Kennedy, Emilia. "From Petro-States to 'new realities': Perspectives on the Geographies of oil." Geography Compass 8.4 (2014): 262-276.

[42] Kruyt, Bert, et al. "Indicators for energy security." Energy policy 37.6 (2009): 2166-2181. 
[43] Lash, Scott. "Power after hegemony: Cultural studies in mutation?." Theory, culture \& society 24.3 (2007): 55-78.

[44] Li, Tania Murray. "Centering labor in the land grab debate." The Journal of Peasant Studies 38.2 (2011): 281-298.

[45] Lilliestam, Johan, and Saskia Ellenbeck. "Energy security and renewable electricity trade-Will Desertec make Europe vulnerable to the "energy weapon"?." Energy policy 39.6 (2011): 33803391.

[46] Martinez, Jose C.: "Bread Is Life - The Intersection of Welfare Policies and Emergency Aid in Jordan", Middle East Research and Information Project, MER 272, available at:

http://www.merip.org/mer/mer272/bread-life (accessed July 20, 2017).

[47] Mas, Cedric, Syria: A Nonsensical 'Pipeline-Triggered' War Theory Debunked. https://kurultay.fr/blog/?p=1103 (accessed July 6, 2017).

[48] McGowan, Francis. "Putting energy insecurity into historical context: European responses to the energy crises of the 1970s and 2000s." Geopolitics 16.3 (2011): 486-511.

[49] Mitchell, Timothy. "Carbon democracy." Economy and Society 38.3 (2009): 399-432.

[50] Mitchell, Timothy. Carbon democracy: Political power in the age of oil. Verso Books, 2011.

[51] Mitchell, Timothy. Rule of experts: Egypt, techno-politics, modernity. Univ of California Press, 2002.

[52] Mostafaeipour, Ali, and Neda Mostafaeipour. "Renewable energy issues and electricity production in Middle East compared with Iran." Renewable and Sustainable Energy Reviews 13.6 (2009): 1641-1645.

[53] Patel, Raj. "Food sovereignty." The Journal of Peasant Studies 36.3 (2009): 663-706.

[54] Pepe Escobar, Syria's Pipelineistan War , Al Jazeera Opinion, August 6, 2012, http://www.aljazeera.com/indepth/opinion/2012/08/201285133440424621.html (accessed June 7, 2017)

[55] Perthes, Volker. The political economy of Syria under Asad. London: IB Tauris, 1997.

[56] Plan C. "Feed the Revolution: An Interview with Rojava Plan". weareplanc.org, June 8, 2016, available at: https://www.weareplanc.org/blog/feed-the-revolution-an-interview-with-rojavaplan/ (accessed June 8, 2017)

[57] Popkin, Barry M., and Penny Gordon-Larsen. "The nutrition transition: worldwide obesity dynamics and their determinants." International journal of obesity 28.S3 (2004): S2.

[58] Ross, Michael L. "Does oil hinder democracy?." World politics 53.3 (2001): 325-361.

[59] Sabio, O.Rojava: An Alternative to Imperialism, Nationalism and Islamism in the Middle East, lulu.com (2015), p 464

[60] Schaffartzik, Anke, et al. "The global metabolic transition: Regional patterns and trends of global material flows, 1950-2010." Global Environmental Change 26 (2014): 87-97.

[61] Selby, J., et al. "Climate change and the Syrian civil war revisited." Political Geography 61 (2017).

[62] Siddiqi, Afreen, and Laura Diaz Anadon. "The water-energy nexus in Middle East and North Africa." Energy policy 39.8 (2011): 4529-4540.

[63] Smith, Neil. "Nature as accumulation strategy." Socialist register 43.43 (2009).

[64] Smith, Neil. Uneven development: Nature, capital, and the production of space. University of Georgia Press, 2010.

[65] Sputnik News. "Thirst Wars: Turkey Applies Political Pressure by Cutting Off Water Supplies", Sputnik News, 8 March 2017, https://sputniknews.com/middleeast/201703081051370769-turkeysyria-water-euphrates/ (accessed June 8, 2017).

[66] Swyngedouw, Erik. Liquid power: contested hydro-modernities in twentieth-century Spain. MIT Press, 2015.

[67] Syrian Kurdish region witnessing campaign of 'Organic Agriculture in Rojava', Cooperative Economy in Rojava \& Bakur, May 16, 2016, https://cooperativeeconomy.info/syrian-kurdishregion-witnessing-campaign-of-organic-agriculture-in-rojava/ (accessed July 5, 2017) 
[68] Tekin, Ali, and Iva Walterova. "Turkey's geopolitical role: the energy angle." Middle East Policy 14.1 (2007): 84.

[69] Tekin, Ali, and Paul A. Williams. "EU-Russian Relations and Turkey's Role as an Energy Corridor." Europe-Asia Studies 61.2 (2009): 337-356

[70] The Rojava Electricity Project, https://www.indiegogo.com/projects/the-rojava-electricityproject-23k-in-23-days\#/ (accessed 20 July, 2017)

[71] von Lossow, Tobias. "The Rebirth of Water as a Weapon: IS in Syria and Iraq." The International Spectator 51.3 (2016): 82-99.

[72] Wilkin, S: Saudi Arabia Cuts Oil Price to Asia as Iran Battle Heats Up, Bloomberg Markets, 31 July 2016, available at: https://www.bloomberg.com/news/articles/2016-07-31/saudis-lower-oilprice-to-asia-most-in-10-months-in-sign-of-glut (accessed 3 July 2017)

[73] Williams, Aled, and Philippe Le Billon, eds. Corruption, Natural Resources and Development: From Resource Curse to Political Ecology. Edward Elgar Publishing, 2017.

[74] Wittfogel, K. A. (1959). Oriental despotism: A comparative study of total power.

[75] Woertz, Eckart. "The governance of Gulf agro-investments." Globalizations 10.1 (2013): 87104

[76] Yetiv, Steve A., and Chunlong Lu. "China, global energy, and the Middle East." The Middle East Journal 61.2 (2007): 199-218.

[77] Zana, Salvador (2016) Mesopotamia: the War for Land and Water, Tuesday, April 26, 2016, http://rojavaplan.com/articles/2016/4/mesopotamia:-the-war-for-land-and-water.html (accessed 07.06.2016)

[78] Bryant, Gareth. "Nature as Accumulation Strategy? Finance, Nature, and Value in Carbon Markets." Annals of the American Association of Geographers (2017): 1-15.

[79] Fuchs, Christian. Digital Labour and Karl Marx. London: Routledge, 2014.

[80] Fischer-Kowalski, Marina, and Helmut Haberl, eds. Socioecological transitions and global change: Trajectories of social metabolism and land use. Edward Elgar Publishing, 2007.

[81] Bookchin, Murray. The Philosophy of Social Ecology Essays on Dialectical Naturalism. London : Black Rose Books, 1998 